\title{
Shelf-Life of Indian White Shrimp Fenneropenaeus indicus Stored in Different Icing Conditions
}

\author{
Mamdoh T. Jamal and T. A. Bin Alshekh AbuBakar \\ Faculty of Marine Science, King Abdulaziz University, \\ P.O.Box 80207 Jeddah 21589, Saudi Arabia \\ mjamal1@kau.edu.sa
}

\begin{abstract}
The Shelf-life of farmed Indian white shrimp Fenneropenaeus indicus, formerly Penaeus indicus stored in ice using three different ratios of ice for 22 days was evaluated. During the storage period, changes in sensory characteristics, TMA-N levels, $\mathrm{pH}$ values and total bacterial count (TBC) were investigated, where the results showed a clear deterioration in the appearance, texture and odor of F. indicus from the 10th day in the samples stored at a shrimp to ice ratio of 1:1 and from the 12th day in the samples stored at a ratio of $1: 2$, while no such deterioration was observed in the samples stored at ratio of 1:3 until the 18th day of storage. The TMA-N levels increased with time during the icing storage. The TBC of the normal flora in the flesh of F. indicus increased with the time of storage. Changes in the sensory characteristics were associated with the changes in TMA$\mathrm{N}, \mathrm{pH}$ and TBC, showing that the 1:2 ratio did not significantly extend the shrimp shelf-life compared to $1: 1$, whereas $1: 3$ significantly delayed the deterioration rate of quality, providing the longest shelf-life and the highest quality shrimp. The shelf-life extended to 9 , 11 and 17 days at ratios of $1: 1,1: 2$ and 1:3 (shrimp to ice), respectively. Therefore, for storage purposes in ice, using a large amount of ice at a 1:3 ratio is recommended, as it extended the shelf-life to the greatest extent in this study.
\end{abstract}

Keywords: shelf-life, Indian white shrimp, Fenneropenaeus indicus, sensory analysis, bacterial count, TMA-N

\section{Introduction}

Fish are an important food source for humans, as they contain animal protein with a high nutritional value, and their prices are relatively low compared with other meats. Fish are also available accessible to the poor and rich alike. Amongst fishes and crustaceans, shrimps is important in human nutrition and health. They serve as a rich source of protein, calcium, vitamins and omega-3 highly unsaturated fatty acids (n-3 HUFA), which have been connected to the prevention of cardiovascular diseases (Jamal 2000; Bragagnolo and RodriguezAmaya 2001; Heu et al. 2003; Sirot et al. 2008; Ouraji et al. 2009). On the other hand, they are also accountable for human intoxication and infection, with 10 to $20 \%$ of food-borne illnesses attributed to the consumption of fish (Pilet and Leroi, 2011). Fishes, as well as shrimps, constitute a main 
part of the protein consumption in many places in the world, as they are high in protein (15-20\%) with large amounts of all essential amino acids, and they provide approximately 3.0 billion people around the world with approximately 20 percent of their intake of animal protein (FAO, 2010; Pilet and Leroi, 2011). Penaeid shrimp have been known to inhabit the Red Sea since three centuries ago (De Man, 1882). They are an Indian white shrimp ( $P$. indicus) species originating from the Indian Ocean (Lee and wickins, 1992). There were fewer than 20 fish farms in Saudi Arabia during the 1980s until the 1990s. The number of fish farms increased seriously in 2002 to be 103 farms after that it was increased 10 2008 to be 227 . Generally the aquaculture in the present time locally concentrate on tow species as its high benefits, tilapia in freshwater and white shrimp in marine aquaculture, because of that farmers are now starting to diversify their aquaculture operations into marine fish culture (Fisheries and Aquaculture Sector statistics, 2004). The main guide for the consumer is the shelf life, that regarding to the starting of deterioration in the food and the used procedure (NZFSA, 2005). It is an important property of any food and is of interest to everyone in the food chain, from producers to consumers. Recently, consumers look $\mathrm{h}$ standard of handling between purchase and consumption to minimize unliked changes in the quality of sensory sensory (Kilcast and Subramaniam, 2000). As the shortness of the shelf-life of the shrimp, the evaluation of shelf-life became an important factor to all market staff. High bacterial count does not always mean the spoilage of the food because only some of the total normal bacteria contributes to the spoilage (Anonymous, 1985). $25 \%$ of the supplied food has been lost due to spoilage which is a high percentage globally (Anonymous, 1985). So that, the microbial activity which could cause food spoilage is a field of an important concern. (Gram and Dalgaard, 2002; Gram and Huss, 1996). As the shrimp is a perishable food with high sensitivity to spoilage due to the neutral post mortem $\mathrm{pH}$ of its flesh (> 6), containing of trimethylamine and amino acids, and many other factors increase of deterioration (Man and Jones 2000; Mendes et al.,2002). Sensory factors such as texture, taste, odor, also total bacterial count and trimethylamine-nitrogen or TMA-N usually uses to evaluate the degradation of shrimps (Armenta et al., 2006). The production of TMA-N is dependent on the bacterial activity as well as from an endogenous enzyme (Green-Petersen, 2010). A higher general sensory quality of fish products available to consumers might induce a 
higher consumption of fish. It might also be possible to induce a higher consumption of fish by obtaining more knowledge about how differences in sensory quality influence consumers' preferences for fish products and using this knowledge to guide the industry to design products with high consumer preferences (Green-Petersen, 2010). The present study detects and recommends freshness stages and spoilage stages by using microbial and chemical changes (that occur inside the shrimp's flesh during icing storage) and linking them with sensory changes. It also contributes a proper way to keep the shrimp in ice by recommending a better ratio of shrimp to ice to extend the shelf-life. There have been several studies of the shelf-life of shrimp (Tsironi et al., 2009; Kirschnik et al., 2006; Al-Dagal et al., 2000; Fatima et al., 1988). In one study of the shelf-life of chilled shrimp (Penaeus) collected from five sources in the Arabian Gulf and stored in ice using a 1:1 ratio, changes in microbial psychrotrophs and the chemical and sensory characteristics of shrimp were assessed every $72 \mathrm{hrs}$ for nine days of icy storage (Al-Dagal et al., 2000). There is a lack in the information and studies of storing in ice and the deterioration of shrimp, A comprehensive study is needed to identify freshness and quality indicators of shrimp stored at zero and subzero ice storage (Qingzhu, 2003).

\section{Materials and Methods}

\section{Raw materials and experimental design}

Samples of Indian white shrimp $F$. indicus with an average body weight of $32.8 \mathrm{~g}$ and $14-18 \mathrm{~cm}$ length were collected from the National Aquaculture Group , Al-Lith, Jeddah, Kingdom of Saudi Arabia, preserved immediately with ice in insulated polystyrene containers, and transferred to the laboratories of the Faculty of Marine Sciences building in Obhur. The samples were washed with sterile seawater in a large pot, the average weight and length were determined, and they were stored with ice in layers in clean plastic insulated containers.

The samples were divided into three different treatments differing by the ratio of shrimp to ice (1:1, 1:2 and 1:3). All the shrimp was covered with crushed ice completely to insure the freshness of the samples inside the ice cooler containers. Re-icing was performed every 24 hours, and the temperature of the cooler contents was measured to confirm the difference in temperature among the three treatments of the experiment. The lowest temperature was approximately $1-1.5^{\circ} \mathrm{C}$ in treatment III (1:3 shrimp to ice), the highest was 
approximately $2.5-3{ }^{\circ} \mathrm{C}$ in treatment I $(1: 1$ shrimp to ice), and the intermediate temperature was approximately $1.7-2.5{ }^{\circ} \mathrm{C}$ in treatment II (1:2 shrimp to ice). The containers were stored at room temperature. Throughout the period of study, many samples of shrimp were taken every 72 hours for testing, including chemical, sensory and microbial tests. The study was terminated when the arbitrators rejected samples and when the chemical parameters of spoilage appeared.

Sensory analysis

The sensory characteristics of shrimp were judged by a panel of experienced persons (arbitrators) of Marine Science Faculty who have sufficient experience in this subject, enabling them to detect the primary indicators of spoilage on the basis of a 10 point scale. The sensory characteristics studied included the general appearance (inclusive of color), odor, and texture of shrimp. The scores were given on a decreasing order scale with 10-9 for excellent, 8-7 for good, 6-5 for fair and acceptable, 4-3 for poor and 2-1 for very poor. The score sheet in table (1) was used (Jeyasekaran et al., 2006). The mean of the scores given by the panel represented the general sensory quality of the shrimps. 
Table 1- Score sheet employed for sensory evaluation of Penaeus indicus

\begin{tabular}{|c|c|c|c|}
\hline Score & Odor & General appearance & Texture \\
\hline 10 & $\begin{array}{l}\text { Seaweedy, characteristic } \\
\text { of the species }\end{array}$ & $\begin{array}{l}\text { Head completely attached to body; head, body and tail } \\
\text { with characteristic color }\end{array}$ & $\begin{array}{l}\text { Firm, elastic, hard } \\
\text { shell/body }\end{array}$ \\
\hline 9 & $\begin{array}{l}\text { Slightly seaweedy, fresh- } \\
\text { cut grass }\end{array}$ & $\begin{array}{l}\text { Head still attached to body; head, body and tail with } \\
\text { characteristic color }\end{array}$ & $\begin{array}{c}\text { Fairly firm, slightly } \\
\text { elastic }\end{array}$ \\
\hline 8 & $\begin{array}{l}\text { Slight characteristic odor } \\
\text { of the species }\end{array}$ & $\begin{array}{l}\text { Head, body and tail with slight fading of characteristic } \\
\text { color }\end{array}$ & Slightly soft body/shell \\
\hline 7 & Neutral to bland & $\begin{array}{l}\text { Head, body and tail with slight fading of characteristic } \\
\text { color }\end{array}$ & Slightly soft body/shell \\
\hline 6 & Slightly ammoniacal & $\begin{array}{l}\text { Slightly loose carapace, head with slight blackening; body } \\
\text { and tail exhibiting light black spots and fading of } \\
\text { characteristic color }\end{array}$ & Slightly soft body/shell \\
\hline 5 & Urea, slightly fishy & $\begin{array}{l}\text { Head almost completely black and slightly loose; tail } \\
\text { exhibiting marked discoloration }\end{array}$ & Soft body and shell \\
\hline 4 & Offensive, sulfide & $\begin{array}{l}\text { Head loose and almost completely black; body and tail } \\
\text { exhibiting black color }\end{array}$ & Soft body and shell \\
\hline 3 & Ammoniacal, sulfide & $\begin{array}{l}\text { Head slightly detached from body and almost completely } \\
\text { black; body and tail black in color }\end{array}$ & Sponge-like body \\
\hline 2 & Strong sulfide & $\begin{array}{l}\text { Head slightly detached from body and completely black; } \\
\text { body and tail exhibiting dark black color }\end{array}$ & Body sponge-like \\
\hline 1 & $\begin{array}{l}\text { Strong sulfide, urea, fecal, } \\
\text { strong ammoniacal }\end{array}$ & $\begin{array}{l}\text { Head slightly to completely detached from body and } \\
\text { completely black; body and tail exhibiting dark black } \\
\text { color }\end{array}$ & $\begin{array}{c}\text { Mushy, very soft } \\
\text { papery shell }\end{array}$ \\
\hline
\end{tabular}




\section{Microbiological analysis}

The direct viable count (DVC) method was used to measure the total bacterial count (TBC) of normal flora in the flesh of the marine shrimp $F$. indicus. The TBC was estimated by the surface inoculation of 0.1 $\mathrm{ml}$ of five dilutions using a digital pipette on Marine Agar (2216 oxoid) plates in triplicate and incubation at $20.7^{\circ} \mathrm{C}$ for 7 days. The colonies developed on the plates were counted and expressed as colony forming units, and the $\mathrm{cfu} / \mathrm{g}$ was calculated.

\section{pH measurement}

Sample of shrimp flesh (10 g) was minced and transferred to a beaker (capacity of 250 $\mathrm{ml}$ ) with $90 \mathrm{ml}$ distilled water and was homogenized by shaking for 60s (Tsironi et al., 2009). The $\mathrm{pH}$ of this homogenized sample was measured using a $\mathrm{pH}$ meter (Amel Instruments 338 pH meter).

\section{Measurements of TMA-N}

The trimethylamine-nitrogen (TMA-N) in shrimp was extracted and estimated by homogenizing $10 \mathrm{~g}$ of shrimp flesh with 20 $\mathrm{ml}$ of $7.5 \%$ (mass/volume) aqueous trichloroacetic acid (TCA) solution and subsequently centrifuging the homogenate at $3000 \mathrm{rpm}$ for $15 \mathrm{~min}$. The supernatant liquid was placed in a volumetric flask and enough $7.5 \%$ TCA was added to make up a total volume of $25 \mathrm{ml}$. A $2 \mathrm{ml}$ volume of the shrimp extract was placed into a $40 \mathrm{ml}-$ amber vial containing a stirring bar together with $5 \mathrm{ml}$ of a salted (30\% mass/volume $\mathrm{NaCl}$ ) aqueous solution and $1 \mathrm{ml}$ of formaldehyde (39\% mass/volume). Then, 2 $\mathrm{ml}$ of $\mathrm{NaOH}(10 \mathrm{M})$ were injected through the septum. A $3 \mu 1$ xylene drop containing $0.015 \%$ mass/volume of picric acid was then formed at the needle tip of a microsyringe and exposed to the headspace of the sample stirred at $1100 \mathrm{rpm}$ for 3.5 min. The extract solution must be refrigerated in a water-ice bath before extraction to extend the extraction time and thereby enhance the extraction efficiency of TMA-N. Finally, the extract solution was placed on the pedestal of a spectrophotometer to obtain the corresponding analytical signal (PenaPereira et al., 2010).

\section{Data analysis}

Statistical analysis was performed using the statistical package SPSS, version 18 . Descriptive statistics (mean \pm standard deviation or standard error) of the analysis results of the physical, chemical and microbiological data were calculated for each treatment. Significant differences between treatment means was determined by a parameters method using one-way ANOVA followed by Duncan's test $(P<$ 
0.05). Sensorial data were analyzed by a non-parametric method using the KruskalWallis test (Kirschnik et. al. 2006, Kruskal and Wallis 1952).

\section{Results}

\section{Sensory analysis}

Table 2- Panel scale of sensory characteristics of $F$. indicus during storage in the three different icing conditions.

\begin{tabular}{|c|c|c|c|c|c|c|c|c|c|}
\hline \multirow{3}{*}{ Days } & \multicolumn{9}{|c|}{ Treatments ${ }^{*}$} \\
\hline & \multicolumn{3}{|c|}{ Treatment (I) } & \multicolumn{3}{|c|}{ Treatment (II) } & \multicolumn{3}{|c|}{ Treatment (III) } \\
\hline & Odor & $\begin{array}{c}\text { General } \\
\text { appearance }\end{array}$ & Texture & Odor & $\begin{array}{c}\text { General } \\
\text { appearance }\end{array}$ & Texture & Odor & $\begin{array}{c}\text { General } \\
\text { appearance }\end{array}$ & Texture \\
\hline $1 \mathrm{st}$ & $9.9 \pm 0.08^{a}$ & $9.9 \pm 0.06^{\mathrm{a}}$ & $9.9 \pm 0.06^{\mathrm{a}}$ & $9.9 \pm 0.58^{\mathrm{a}}$ & $9.9 \pm 0.06^{\mathrm{a}}$ & $9.9 \pm 0.06^{\mathrm{a}}$ & $9.9 \pm 0.058^{\mathrm{a}}$ & $9.9 \pm 0.06^{\mathrm{a}}$ & $9.9 \pm 0.06^{\mathrm{a}}$ \\
\hline 4 th & $9.1 \pm 0.15^{b}$ & $8.5 \pm 0.15^{b}$ & $9.6 \pm 0.15^{\mathrm{a}}$ & $9.5 \pm 0.25^{\mathrm{ab}}$ & $9.1 \pm 0.15^{\mathrm{ab}}$ & $9.8 \pm 0.06^{\mathrm{ab}}$ & $9.7 \pm 0.058^{a}$ & $9.5 \pm 0.15^{\mathrm{ab}}$ & $9.8 \pm 0.10^{\mathrm{a}}$ \\
\hline 7 th & $8.1 \pm 0.21^{\mathrm{c}}$ & $7.2 \pm 0.20^{c}$ & $8.5 \pm 0.15^{b}$ & $8.3 \pm 0.21^{b c}$ & $8.8 \pm 0.15^{\mathrm{ab}}$ & $8.8 \pm 0.15^{b}$ & $9.1 \pm 0.21^{\mathrm{a}}$ & $9.1 \pm 0.15^{b c}$ & $9.6 \pm 0.15^{\text {ab }}$ \\
\hline 10th & $6.4 \pm 0.21^{\mathrm{d}}$ & $6.5 \pm 0.60^{c}$ & $6.3 \pm 0.43^{c}$ & $7.5 \pm 0.50^{c}$ & $8.1 \pm 0.21^{b}$ & $7.2 \pm 0.20^{c}$ & $8.2 \pm 0.36^{b}$ & $8.5 \pm 0.15^{\mathrm{cd}}$ & $9.1 \pm 0.21^{b}$ \\
\hline 13th & $4.5 \pm 0.23^{\mathrm{e}}$ & $2.7 \pm 0.25^{\mathrm{d}}$ & $4.4 \pm 0.58^{\mathrm{d}}$ & $7.1 \pm 0.26^{\mathrm{c}}$ & $5.5 \pm 0.53^{c}$ & $6.7 \pm 0.21^{\mathrm{c}}$ & $7.5 \pm 0.25^{b c}$ & $8.1 \pm 0.21^{\mathrm{d}}$ & $7.5 \pm 0.25^{c}$ \\
\hline 16th & $2.4 \pm 0.31^{f}$ & $2.0 \pm 0.32^{\mathrm{d}}$ & $2.1 \pm 0.43^{\mathrm{e}}$ & $5.4 \pm 0.49^{\mathrm{e}}$ & $3.0 \pm 0.85^{\mathrm{d}}$ & $4.3 \pm 0.26^{d}$ & $7.1 \pm 0.40^{\mathrm{c}}$ & $7.1 \pm 0.26^{\mathrm{e}}$ & $6.4 \pm 0.21^{\mathrm{d}}$ \\
\hline 19th & $1.3 \pm 0.46^{\mathrm{g}}$ & $1.1 \pm 0.21^{\mathrm{e}}$ & $1.3 \pm 0.46^{\mathrm{ef}}$ & $4.5 \pm 0.26^{\mathrm{ef}}$ & $2.0 \pm 0.32^{\text {de }}$ & $3.0 \pm 0.85^{\mathrm{e}}$ & $6.1 \pm 0.38^{\mathrm{d}}$ & $5.2 \pm 0.53^{f}$ & $4.6 \pm 0.31^{\mathrm{e}}$ \\
\hline $22^{\text {nd }}$ & $1.1 \pm 0.23 \mathrm{~g}$ & $1.0 \pm 0.15^{\mathrm{e}}$ & $1.0 \pm 0.15^{f}$ & $3.1 \pm 0.86^{\mathrm{f}}$ & $1.0 \pm 0.18^{\mathrm{e}}$ & $1.0 \pm 0.15^{f}$ & $5.2 \pm 0.30^{\mathrm{e}}$ & $2.9 \pm 0.26^{\mathrm{g}}$ & $4.0 \pm 0.29^{\mathrm{e}}$ \\
\hline
\end{tabular}

* Treatment (I) ; 1shrimp : 1 ice ratio. Treatment (II); 1shrimp: 2 ice ratio. Treatment (III); 1shrimp: 3 ice ratio. Values are means \pm standard error (SE). Different small letters in each column indicate significant differences $(P<0.05)$.

\section{Microbiological analysis}

The $\mathrm{TBC}$ in the three different conditions were measured during the storage in ice, as is shown in table (3). Generally, the bacterial load in the flesh increased from an initial load of $3.41 \times 10^{3} \mathrm{cfu} / \mathrm{g}$ to $5.30 \times 10^{6}$
The changes in the sensory properties of $F$. indicus stored with ice in three different icing conditions for 22 days in this study are shown in table (2). The freshness was judged by the group of experts on the basis of sensory characteristics such as texture, general appearance and odor. 
Table 3- Total bacterial count (TBC cfu/g) of normal flora in the flesh of $F$. indicus during storage in ice in the three different conditions.

\begin{tabular}{cccc}
\hline Days & Treatment (I) & Treatment (II) & Treatment (III) \\
& & & \\
\hline $\mathbf{1}^{\text {st }}$ & $3.41 \times 10^{3} \pm 2.37 \times 10^{1} \mathrm{a}^{*}$ & $3.41 \times 10^{3} \pm 2.37 \times 10^{1} \mathrm{a}$ & $3.41 \times 10^{3} \pm 2.37 \times 10^{1} \mathrm{a}$ \\
$\mathbf{4}^{\text {th }}$ & $4.33 \times 10^{3} \pm 5.77 \times 10^{1} \mathrm{a}$ & $\mathrm{ND}$ & $3.66 \times 10^{3} \pm 8.43 \times 10^{2} \mathrm{a}$ \\
$\mathbf{7}^{\text {th }}$ & $\mathrm{ND}^{* *}$ & $\mathrm{ND}$ & $7.85 \times 10^{3} \pm 5.08 \times 10^{2} \mathrm{~b}$ \\
$\mathbf{1 0}^{\text {th }}$ & $1.25 \times 10^{5} \pm 8.08 \times 10^{3} \mathrm{ab}$ & $3.70 \times 10^{4} \pm 1.16 \times 10^{3} \mathrm{a}$ & $1.02 \times 10^{4} \pm 5.77 \times 10^{1} \mathrm{c}$ \\
$\mathbf{1 3}^{\text {th }}$ & $2.74 \times 10^{5} \pm 9.24 \times 10^{3} \mathrm{~b}$ & $1.10 \times 10^{5} \pm 1.73 \times 10^{3} \mathrm{~b}$ & $5.35 \times 10^{4} \pm 1.20 \times 10^{3} \mathrm{~d}$ \\
$\mathbf{1 6}^{\text {th }}$ & $5.25 \times 10^{5} \pm 1.27 \times 10^{4} \mathrm{c}$ & $4.46 \times 10^{5} \pm 3.35 \times 10^{4} \mathrm{c}$ & $8.90 \times 10^{4} \pm 5.77 \times 10^{2} \mathrm{e}$ \\
$\mathbf{1 9}^{\text {th }}$ & $\mathrm{ND}$ & $1.71 \times 10^{6} \pm 1.73 \times 10^{3} \mathrm{~d}$ & $6.40 \times 10^{5} \pm 5.77 \times 10^{2} \mathrm{f}$ \\
$\mathbf{2 2}^{\text {nd }}$ & $5.30 \times 10^{6} \pm 1.86 \times 10^{5} \mathrm{~d}$ & $4.80 \times 10^{6} \pm 9.24 \times 10^{3} \mathrm{e}$ & $9.06 \times 10^{5} \pm 5.77 \times 10^{2} \mathrm{~g}$ \\
\hline
\end{tabular}

*Means \pm standard error (SE). Mean values are obtained from three samples analyzed in triplicate. Different letters in each column indicate a significant difference $(P<0.05)$ based on the one-way analysis of variance of raw data followed by Duncan's post hoc test. **ND= No data found.

\section{pH measurement}

The changes in the $\mathrm{pH}$ values of the shrimp flesh in the three different icing conditions are shown in table (4). The results indicate Table 4- Changes in $\mathrm{pH}$ values of flesh of shrimp $F$. indicus during storage in ice in the three different conditions.

\begin{tabular}{cccc}
\hline Days & Treatment (I) & $\begin{array}{c}\text { Treatment } \\
\text { (II) }\end{array}$ & $\begin{array}{c}\text { Treatment } \\
\text { (III) }\end{array}$ \\
\hline $1^{\text {st }}$ & 6.76 & 6.76 & 6.76 \\
$4^{\text {th }}$ & 6.82 & 6.77 & 6.75 \\
$7^{\text {th }}$ & 6.87 & 6.78 & 6.75 \\
$10^{\text {th }}$ & 6.95 & 6.84 & 6.80 \\
$13^{\text {th }}$ & 7.03 & 6.96 & 6.83 \\
$16^{\text {th }}$ & 7.10 & 7.00 & 6.87 \\
$19^{\text {th }}$ & 7.49 & 7.14 & 7.03 \\
$22^{\text {th }}$ & 7.68 & 7.49 & 7.44 \\
\hline
\end{tabular}

that the $\mathrm{pH}$ values increased during storage in the three treatments from 6.76 to 7.68 in treatment (I), to 7.49 in treatment (II), and to 7.44 in treatment (III) at $P<0.05$.

* Treatment (I) ; 1shrimp : 1 ice ratio. Treatment (II); 1 shrimp: 2
ice ratio. Treatment (III); 1shrimp: 3 ice ratio. Values are means.

Measurements of TMA-N

Changes in the trimethylamine-nitrogen (TMA$\mathrm{N})$ levels in Indian white shrimp ( $F$. indicus) stored in different ratios of ice are shown in figure (1). The TMA-N results of show increasing trends, the first significant increases at $P<0.05$ observed on the $4^{\text {th }}$ day for all three treatments, gradually continuing the first treatment (I) until the $22^{\text {nd }}$ day (Fig. 1). 


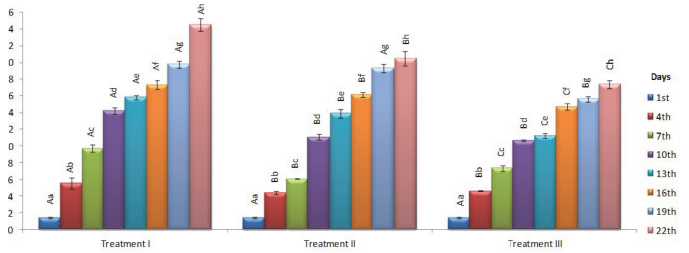

Figure 1- Changes in TMA-N values in $F$. indicus in the three treatments during storage in ice.

Means in the same treatment followed by different lowercase letters and means in the same day of each treatment followed by different capital letters, are significantly different $(P<0.05)$. Treatment I = shrimp to ice 1:1 ratio, Treatment II = shrimp to ice $1: 2$ ratio, Treatment $\mathrm{III}=$ shrimp to ice $1: 3$ ratio.

\section{Discussion}

\section{Sensory analysis}

In table (2) the sensory analysis of the stored Indian white shrimp ( $F$. indicus) show that the lowest sensory scores were given to the shrimp stored in ice at 1:1 and 1:2 shrimp to ice ratios. The shrimp stored in ice at a 1:3 ratio was awarded the highest sensory scores, indicating a higher quality or a slower spoilage rate than in the other treatments throughout the storage period. Similar effects were observed in a previous study of quality changes of shrimp (Zeng et al., 2005). The shelf-lives of the samples in the three treatments were as follows. The shrimps stored in ice at the 1:1 ratio were found to be organoleptically suitable for consumption when they were stored for 9 days with daily re-icing, similar to results reported in previous studies about the shelflife of $P$. indicus stored in ice (Al-Dagal et al., 2000, Joseph et al., 1998). Shrimps stored in ice at the 1:2 ratio were acceptable up to 11 days, while shrimps stored in ice at the ratio of 1:3 were found to be acceptable up to 17 days. To maintain the quality of fresh shrimp, it must be stored with a 1:3 ratio of shrimp to ice, depending on the conditions and the storage period (Hendiy, 1983).

\section{Microbiological analysis}

The total bacterial count (TBC) of normal flora in Indian white shrimp ( $F$. indicus) stored in ice in three different conditions $(1: 1,1: 2,1: 3$ ratios) showed that the TBC in the flesh at the start of measurements (24 hours after the catch) was measured as 3.41 x $10^{3} \mathrm{cfu} / \mathrm{g}$. When comparing the TBC results in this study with the standard limit $\left(10^{5} \mathrm{cfu} / \mathrm{g}\right)$ from ICMSF, (1986), the results show that the TBC in the flesh did not exceed the limit until the $16^{\text {th }}$ day of the experiment for the $1: 1$ and $1: 2$ ratios, and for the 1:3 ratio, it did not reach the standard limit until the end of the experiment. Generally, as shown in table (3), a lower bacterial load was observed in the 1:3 ratio, indicating that this treatment helps reduce the bacterial load in shrimp. It could also be explained by the reduction of the temperature in the 1:3 ratio compared with the $1: 1$ and $1: 2$ ratios. The increase of 
melted water in the $1: 1$ and $1: 2$ ratios during the 24 hours before the re-icing and draining of the liquid water could also help the bacteria increase in number (Zeng et al., 2005).

\section{pH measurement}

The $\mathrm{pH}$ values of shrimp meat provide valuable information about its quality change. In the three treatments, the $\mathrm{pH}$ value of the Indian white shrimp $F$. indicus stored in ice was recorded to be between 6.76 to 6.87 until the $7^{\text {th }}$ day of storage in ice (Table 4). The measurement of the $\mathrm{pH}$ continued until the end of experiment, with the $\mathrm{pH}$ value increasing to 7.68 by the $22^{\text {nd }}$ day of the experiment with a 1:1 ratio and to 7.49 with a $1: 2$ ratio. The ratio of $1: 3$ recorded a $\mathrm{pH}$ value of 7.44 on the $22^{\text {nd }}$ day of storage, a lower value. In a previous study on the shelf-life of $P$. indicus stored in ice, the $\mathrm{pH}$ at the beginning of the experiment recorded a high value (7.18 7.25 ) and reached 7.70 on the $9^{\text {th }}$ day of the study (Al-Dagal et al., 2000), while in the present study, it did not exceed 7.00 until the $10^{\text {th }}$ day for the $1: 1$ ratio, the $13^{\text {th }}$ day for the $1: 2$ ratio, and the $16^{\text {th }}$ day for the $1: 3$ ratio.

$\mathrm{pH}$ values between $7.50-7.75$ are still accepted as safe values for food and are not considered spoilage indicators (Nickelson, 1992).

\section{Measurements of TMA-N}

The TMA-N levels increased gradually in all three treatments during the iced storage $(P<0.05)$. The increase in TMA-N has been recorded by many previous studies of P. indicus stored in ice (Bindu et al., 2012). The TMA-N level, which indicates the extent of protein breakdown, usually by bacteria or enzymes, gradually increased with storage time, as observed in earlier studies (Mahmud et al., 2007; Ali et al., 2010; Reddy et al., 2012).

The acceptable limit of TMA-N for fishery products is in the range of $10-15 \mathrm{mg} / 100 \mathrm{~g}$ (Connell ,1995). The TMA-N levels in the present study exceeded the acceptable limit by the $10^{\text {th }}, 13^{\text {th }}$, and $16^{\text {th }}$ day in the $1: 1,1: 2$ and 1:3 ratios, respectively (Fig. 1). Considering the sensory results, which indicate that the shrimp samples were still acceptable on day 16 at 1:2 ratio and day 19 at the 1:3 ratio (Table 2), it could be argued that TMA-N may not be a suitable spoilage indicator, or otherwise the threshold values may be shifted upwards for white shrimp. The TMA-N levels in the shrimp stored with a $1: 3$ ratio were within the acceptable limit of $10-15 \mathrm{mg} / 100 \mathrm{~g}$ during the first 16 days of the experiment but increased by the 
$19^{\text {th }}$ day of the storage period to above 15 $\mathrm{mgN} / 100 \mathrm{~g}$, although they were still organoleptically rated as acceptable. While they were within the acceptable limit $(<14$ $\mathrm{mgN} / 100 \mathrm{~g}$ ) and they were organoleptically rated as acceptable at the $1: 2$ ratio until the $13^{\text {th }}$ day of storage, they increased to $20.5 \mathrm{mgN} / 100 \mathrm{~g}$ by the $22^{\text {nd }}$ day of the storage period. At a ratio of $1: 1$, the TMA-N levels of the shrimp were within the acceptable limit until the $10^{\text {th }}$ day $(<14.3 \mathrm{mgN} / 100 \mathrm{~g})$ but increased to 24.6 $\mathrm{mg} \mathrm{N} / 100 \mathrm{~g}$ by the $22^{\text {nd }}$ day of storage. The TMA-N was significantly different for different storage periods (Fig. 1). In general, the TMA-N values stayed well below the acceptable limit $(10-15 \mathrm{mg} / 100$ g) during the first 7 days of the experiment. Statistically, there are significant effects observed in the increase in the TMA-N value when using different ratios of ice in this study at $P<0.05$. Figure (1) shows that the $1: 3$ ratio was the best treatment to extend the shelf-life of shrimp stored in ice, and a reduction in the TMA-N values was noticed upon increasing the ratio of ice to shrimp in the three treatments during the storage period $(P<0.05)$.

\section{Conclusions}

The amount of ice used has a direct effect on the shelf-life and product quality of $F$. indicus, as a large amount of ice causes comparatively less spoilage than a small amount. A 1:3 ratio of shrimp to ice creates unfavorable environmental conditions for bacteria, which slows down the bacterial growth and thereby increases the shelf-life, while a ratio of 1:1 allows increased bacterial growth, which reduces the shelflife. Therefore, it is recommended to use a large amount of ice to extend the shelf-life, as observed in the shrimp to ice ratio of 1:3 in this study. TMA-N was shown to be a good indicator of shrimp spoilage in this study, and its levels increased during the ice storage. The high levels of TMA-N indicated critical and advanced stages of shrimp spoilage. The total bacterial count (TBC) of the normal flora in F. indicus also showed increases with the time of storage, and higher levels were recorded in the 1:1 and $1: 2$ ratios.

Generally, the shelf-life of $F$. indicus in treatment (III) was found to be 17 days, compared with 9 and 11 days in (I) and (II), respectively.

From the present study, the recommendations are as follows:

1) As shrimp is an important source of animal protein, there is a need for further studies to mitigate the losses of the world's food supply caused by incorrect storage methods, which exceeds $25 \%$ globally. 
2) It is recommended to use a shrimp to ice ratio of $1: 3$, to extend the shelf-life for shrimp.

3) A comprehensive study of the normal bacterial flora in water and caught shrimp, which also have an effect on the storage of shrimp, could help to further extend the shelf-life.

\section{References}

Ali, M.Y., Sharif, M.I., Adhikari, R.K. and Faruque, O. (2010) Post mortem variation in Total Volatile Base Nitrogen and Trimethylamine Nitrogen between Galda (Macrobrachium rosenbergii) and Bagda (Penaeus monodon). Rajshahi University Zoological Society, 28:07-10.

Al-Dagal, M.M., Al-Khalifa, S.M. and Al-Sheddy, I.A. (2000) Shelf Life of Chilled Shrimp from Main Wholesale Outlet in Al-Qatif City (Eastern Province) Journal of King Saud University. Agriculture Science Riyadh. Saudi Arabia 12: 3-17.

Anonymous (1985) An Evaluation of the Role of Microbiological Criteria for Foods and Food Ingredients. National Research Council, National Academy Press. Washington, DC, USA.
Armenta, S., Coelho, N.M., Roda, R., Garrigues, S. and Guardia, M. (2006) Seafood freshness determination through vapour phase Fourier transform infrared spectroscopy. Analytica Chimica Acta 580: 216-222.

Bindu, J, Ginson, J., Kamalakanth, C.K., Asha, K.K., and Srinivasa Gopal, T.K. (2017) Physico-chemical changes in high pressure treated Indian white prawn (Fenneropenaeus indicus) during chill storage. Innovative Food Science and Emerging Technologies. a PDF file of an unedited manuscript that has been accepted for publication. Accepted date: 12 October 2017.

Bragagnolo, N. and Rodriguez-Amaya, D.B. (2001) Total lipid, cholesterol and fatty acid composition of farmed fresh water prawn (Macrobrachium rosenbergii) and wild marine shrimp (Penaeus brasiliensis, Penaeus schimitti, Xiphopenaeus kroyeri). Journal of Food Composition and Analysis 14:359-369.

Connell, J.J. (1995) Control of Fish Quality. pp.245. Fishing News Books Ltd., England.

FAO (2010) The state of world fisheries and aquaculture. Available from http://www.fao.org/docrep/013/i1820e/i182 0e00.htm . Accessed on Sept. 26, 2013. 
FAO (2012) The state of world fisheries and aquaculture. Available from http://www.fao.org/docrep/016/i2727e/i272 7e.pdf . Accessed on Sept. 21, 2013.

Gram, L. and Dalgaard, P. (2002) Fish spoilage bacteria-problems and solutions. Current Opinion in Biotechnology. 13(3):262-266.

Gram, L. and Huss, H.H. (1996) Microbiological spoilage of fish and fish products. International Journal of Food Microbiology. 33(1):121-137.

Green-Petersen, D. (2010) Sensory Quality of Seafoodin the chain from catch to consumption. PhD Thesis. National Food Institute, Technical University of Denmark.

Hendiy, M. J. (1983) Technology of fishery products. Translated into Arabic, University of Basra, Iraq. pp: 853.

Heu, M.S., Kim, J.S. and Shahidi, F. (2003) Components and nutritional quality of shrimp processing by-products. Food Chem. 82:235-242.

Huss, H.H., Dalsgaard, D., Hansen, L., Ladefoged, H., Pedersen, A., and Zittan, L. (2007) The influence of hygiene in catch handling on the storage life of iced cod and plaice. International Journal of Food Science \& Technology 9(2):213-221.
ICMSF (International Commission on Microbial Specification for Foods) (1986) Microorganisms in foods. In: Application of the Hazard Analysis Critical Control Point (HACCP) System to Ensure Microbiological Safety and Quality. p. 42. Blackwell Scientific Publications.

Jamal, M.T.A. (2000) Microflora of fresh and ice stored grouper (Epinephelus polyphekadion) with emphasis on spoilage and shelf-life. Master thesis, Department of Marine Biology at the Faculty of Marine Science, King Abdulaziz University, Saudi Arabia.

Jeyasekaran, G., Ganesan, P., Anandaraj, R., Shakila, R.J. and Sukumar, D. (2006) Quantitative and qualitative studies on the bacteriological quality of Indian white shrimp ( $\underline{\text { Penaeus }}$ indicus) stored in dry ice. Food Microbiology Journal 23: 526-533.

Joseph, J., Perigreen, P.A. and Iyer, T.S.G. (1998) Storage Characteristics of Cultured Penaeus indicus in Ice and at Ambient Temperature. Fishery Technology. 35(2): $84-89$.

Kilcast, D. and Subramaniam, P. (2000) The stability and shelf-life of food. Published by Woodhead Publishing Limited, England. 
Kirschnik, P.G., Viegas, E.M., Valenti, W.C. and Oliveira, C.A.F. (2006) ShelfLife of Tail Meat of the Giant River Prawn, Macrobrachium rosenbergii, Stored on Ice. Journal of Aquatic Food Product Technology. 15(2): 57-71.

Kruskal, W.H. and Wallis, W.A. (1952) Use of Ranks in One-Criterion Variance Analysis. Journal of the American Statistical Association. 47(260):583-621.

Mahmud, M.M., Hossain, M.A., Jahan, I., Banerjee, P. and Rahaman, M.A. (2007) Effect of Delayed Icing on the Quality Characteristics of Bagda (Penaeus Monodon Fabricius, 1798) Int. J. Sustain. Crop Prod. 2(5):24-30.

Man, C. and Jones, A. (2000) Shelf-life evaluation of foods, second edition. Aspen Pub, Icn. 273 pages.

Mendes, R., Huidobro, A. and Caballero, E. (2002) Indole levels in deepwater pink shrimp (Parapenaeus longirostris) from the Portuguese coast. Effects of temperature abuse. European Food Research and Technology. 214(2):125-130.

Nickelson, II, R. (1992) Bacteria of Significance in the International Trade Shrimp. SCOPE. A Technical Bulletin from Silliker Laboratories. 7 No. 2, 1-7, Illinois, USA.
NZFSA [New Zealand Food Safety Authority] (2005) A Guide to Calculating the Shelf Life of Foods. Information Booklet for the Food Industry. Pp 32. Available from http://ebookbrowse.com/aguide-to-calculating-the-shelf-life-offoods-new-zealand-pdfd51077199\#.UKOgUJzcbic. Accessed on Oct. 7, 2013.

Ouraji, H., Shabanpour, B., Kenari, A.A., Shabani, A., Nezami, S., Sudagar, M. and Faghani, S. (2009) Total lipid, fatty acid composition and lipid oxidation of Indian white shrimp (Fenneropenaeus indicus) fed diets containing different lipid sources. J. Sci. Food Agric. 89: 993-997.

Pena-Pereira, F., Lavilla, I. and Bendicho, C. (2010) Colorimetric assay for determination of trimethylaminenitrogen (TMA-N) in fish by combining headspace-single-drop microextraction and microvolume UV-vis spectrophotometry. Food Chemistry Journal. 119:402-407.

Pilet, M. and Leroi, F. (2011) Applications of protective cultures, bacteriocins and bacteriophages in fresh seafood and seafood products. Edited by $\mathrm{C}$ Lacroix, ETH Zurich, Switzerland, Woodhead Publishing Series in Food Science, Technology and Nutrition No. 
201, ISBN-13: $978 \quad 1 \quad 845696696$.

Woodhead Publishing Limited, England.

Qingzhu, Z. (2003) Quality Indicators of Northern (Pandalus borealis) Stored under Different Cooling Conditions. UNUFisheries Training Programme. ICELAND.

Reddy, V.K., Shinde, P.A., Shelar, P.S. and Patange, S.B. (2012) The Influence of Vacuum Packaging in Combination With Sulphite Treatment on Melanosis and Quality of Tiger Shrimp During Ice Storage. Continental J. Food Science and Technology. 6 (3): 10 - 18.

Sirot, V., Oseredczuk, M., Bemrah Aouachria, N., Volatier, J.L. and Leblanc, J.C. (2008) Lipid and fatty acid composition of fish and seafood consumed in France

Tsironi, T., Dermesonlouglou, E., Giannakourou, M. and Taoukis, P. (2009) Shelf life modelling of frozen shrimp at variable temperature conditions. LWT - Food Science and Technology. 42: 664-671.

Zeng, Q.Z., Thorarinsdottir K.A. and Olafsdottir G. (2005) Quality Changes of Shrimp (Pandalus borealis) Stored under Different Cooling Conditions. Journal of Food Science. 70:17-29. 


\title{
Fenneropenaeus indicus العمر التخزيني للروبيان الابيض الهندي
}

\author{
المخزون في ظروف مختلفة في الثلج \\ ممدوح طه جمال ، طارق علوي بن الثيخ أبوبكر

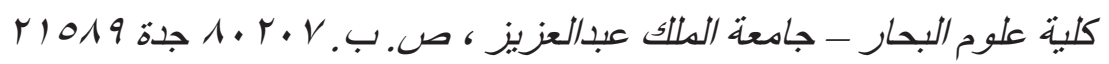 \\ المدلكة العربية السعودية
}

تم تقييم العمر التخزيني الافتراضي لروبيان الاستزراع الهندي الابيض Fenneropenaeus indicus في ثلاث نسب مختلفة من الثلج ولمدة بr يوما، وتم تقيبم عدة عو امل لجودة الروبيان وهي الخصائص الحسية ومستويات التزاي ميثيل امين وكذلك درجة الحموضة و العدد الكلي البكتيري خلال فترة التخزين. وأظهرت النتائج تدهور واضح في الخصائص الحسية من حيث المظهر والملمس والر ائحة للروبيان ابتداءا من اليوم العانشر من التخزين في الثلج لنسبة (1:1) روبيان: تلج، وكان التهور واضحا في جودة الروبيان المخزن بنسبة (1:(Y) روبيان: ثلج، في حين لم يلاحظ التدهور الحسي لجودة الروبيان في التخزين بنسبة (1:) روبيان : ثلج حتى اليوم الثامن عشر من التخزين ـ كما ارتفعت مستويات التزاب ميثيل امين و العدد الكلي للبكتيريا مع استمرار التخزين في التلج. وكان واضحا ارتباط تدهور الخصائص الحسية اثناء فترة التخزين مع التغيرات في مستويات التراي ميثيل امين ودرجة الحموضة والعدد الكلي البكتيري. ودلت النتائج ان نسبة (1:(Y) روبيان: ثلج من التخزين لم تكن ذات جدوي لحفظ جودة الروبيان، كما كان الحال بنسبة التخزين (1: () روبيان : ثلج , مع ظهور فرق كبير ذو جدوى في تخزين الروبيان في ما نسبته (1:؟) روبيان : ثلج , حيث كانت فعالة اكثر في حفظ

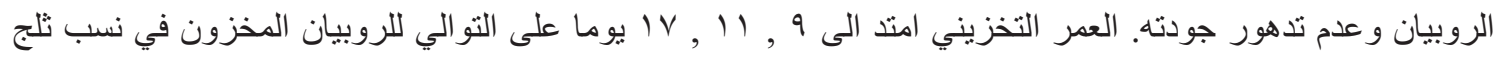

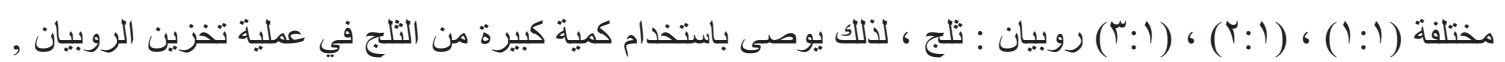
حيث تزيد هذة النسبة من الثلج العمر التخزيني وتحافظ على جودة الروبيان المخزون. 